\title{
Disruption of Two Defensive Signaling Pathways by a Viral RNA Silencing Suppressor
}

\author{
Mathew G. Lewsey, ${ }^{1}$ Alex M. Murphy, ${ }^{1}$ Daniel MacLean, ${ }^{2}$ Neil Dalchau, ${ }^{1}$ Jack H. Westwood, ${ }^{1}$ \\ Keith Macaulay, ${ }^{1}$ Mark H. Bennett, ${ }^{3}$ Michael Moulin, ${ }^{1}$ David E. Hanke, ${ }^{1}$ Glen Powell, ${ }^{3}$ \\ Alison G. Smith, ${ }^{1}$ and John P. Carr ${ }^{1}$ \\ ${ }^{1}$ Department of Plant Sciences, University of Cambridge, Downing Street, Cambridge, CB2 3EA, U.K.; ${ }^{2}$ Sainsbury \\ Laboratory, Norwich Research Park, Norwich, NR4 7UH, U.K.; ${ }^{3}$ Imperial College London, South Kensington Campus, \\ London, SW7 2AZ, U.K.
}

Submitted 10 February 2010. Accepted 16 March 2010.

\begin{abstract}
The Cucumber mosaic virus (CMV) $2 \mathrm{~b}$ counter-defense protein disrupts plant antiviral mechanisms mediated by RNA silencing and salicylic acid (SA). We used microarrays to investigate defensive gene expression in $2 b$-transgenic Arabidopsis thaliana plants. Surprisingly, 2b inhibited expression of few SA-regulated genes and, in some instances, enhanced the effect of $\mathrm{SA}$ on certain genes. Strikingly, the $2 b$ protein inhibited changes in the expression of $90 \%$ of genes regulated by jasmonic acid (JA). Consistent with this, infection of plants with CMV, but not the $2 b$ gene-deletion mutant $\mathrm{CMV} \Delta \mathbf{2 b}$, strongly inhibited JA-inducible gene expression. JA levels were unaffected by infection with either CMV or CMV $\Delta 2$ b. Although the CMV-Arabidopsis interaction is a compatible one, $\mathrm{SA}$ accumulation, usually considered to be an indicator of plant resistance, was increased in CMV-infected plants but not in CMV $\Delta 2 \mathrm{~b}$ infected plants. Thus, the $2 \mathrm{~b}$ protein inhibits JA signaling at a step downstream of JA biosynthesis but it primes induction of SA biosynthesis by another CMV gene product or by the process of infection itself. Like many plant viruses, CMV is aphid transmitted. JA is important in plant defense against insects. This raises the possibility that disruption of JA-mediated gene expression by the $2 \mathrm{~b}$ protein may influence CMV transmission by aphids.
\end{abstract}

Plants employ multiple defense mechanisms, including antiviral RNA silencing and salicylic acid (SA)-mediated defense, to restrict virus replication and movement (Lewsey et al. 2009a). RNA silencing provides adaptive defense against viruses, whereby viral RNAs are used as templates for synthesis of complementary small-interfering (si)RNAs that direct sequencespecific slicing of viral RNA by the RNA-induced silencing complex (RISC) (Baulcombe 2004). Silencing exerts strong selective pressures on viruses and, thus, most have acquired viral suppressors of RNA silencing (VSR) (Lewsey et al. 2009a). The $2 \mathrm{~b}$ protein of Cucumber mosaic virus (CMV) was among the first VSR described (Brigneti et al. 1998). ARGONAUTE (AGO) proteins are the only known protein components of

Current address for N. Dalchau: Microsoft Research, 7 J.J. Thomson Avenue, Cambridge, CB3 OFB, U.K.

Corresponding author: J. P. Carr; E-mail: jpc1005@hermes.cam.ac.uk

* The $e$-Xtra logo stands for "electronic extra" and indicates that three supplementary tables, two supplementary figures, and eight data spreadsheets are published online.
RISC in plants (Baumberger and Baulcombe 2005; Zhang et al. 2006). The $2 \mathrm{~b}$ protein binds to AGO 1 and AGO 4 but predominantly impedes silencing through binding of siRNAs (Zhang et al. 2006; Goto et al. 2007; González et al. 2010).

$\mathrm{SA}$ is a plant hormone required for maintenance of basal resistance and induction of local and systemic acquired resistance to pathogens (Lewsey et al. 2009a). Increased SA levels are associated with the activation of thousands of genes, many of which encode factors with known antifungal or antibacterial effects (Lewsey et al. 2009a). The antiviral effects of SA are less well understood but appear to involve changes in plant gene expression mediated via a NONEXPRESSOR OF PATHOGENESIS-RELATED (PR) GENES 1 (NPR1)-independent signaling pathway, transduced by changes in redox or reactive oxygen species in the mitochondria (Singh et al. 2004; Wong et al. 2002).

Ostensibly, SA-induced resistance, involving the activation of diverse genetically preprogrammed resistance mechanisms, appears to differ considerably from RNA silencing, which is adaptive and directed against specific viral RNA sequences. However, two strong lines of evidence point to a functional overlap or interaction between RNA silencing and SA-mediated defense. First, SA induces the RDR1 class of cellular RNA-directed RNA polymerases, which are involved in the amplification of antiviral RNA silencing (Xie et al. 2001; Gilliland et al. 2003; Yu et al. 2003; Yang et al. 2004). Second, at least two VSR, the $2 \mathrm{~b}$ protein and the potyviral HC-Pro, subvert some of the effects of SA on plant defense ( $\mathrm{Ji}$ and Ding 2001; Pruss et al. 2004; Alamillo et al. 2006). Whether or not the effects of the $2 \mathrm{~b}$ protein and HC-Pro on SA-induced resistance depend on the ability of these factors to suppress silencing remains to be established. However, these studies suggest a role for RNA silencing in at least some aspects of SA-induced virus resistance.

RNA silencing also regulates cellular gene expression via nuclear-encoded short (s)RNAs, micro (mi)RNAs, and transactivating siRNAs (Llave et al. 2002; Allen et al. 2005). Growing evidence indicates that RNA silencing is involved in regulation of hormone signaling. For example, Arabidopsis mutants in HYL1, a gene required for accurate miRNA processing, exhibit altered sensitivity to auxin, cytokinin, and abscissic acid (Han et al. 2004; Dong et al. 2008). Also, expression of HC-Pro or the $2 \mathrm{~b}$ protein in transgenic Arabidopsis results in ectopic expression of several miRNA-regulated transcripts, including those encoding AUXIN RESPONSE FACTORs (ARF) and the miRNAs that target them (Kasschau et al. 2003; Zhang et al. 2006; Lewsey et al. 2007). 
To assess the effects of the $2 \mathrm{~b}$ protein on plant gene expression and SA-mediated defensive signaling, we used DNA microarrays to analyze transcriptional responses to SA treatment of nontransgenic Arabidopsis plants and plants constitutively expressing a $2 b$ transgene. We also investigated the effect of the $2 \mathrm{~b}$ protein on genes regulated by jasmonic acid (JA) and its derivatives, primarily because of the extensive crosstalk between SA- and JA-mediated signaling pathways (Farmer et al. 2003; Howe and Jander 2008; Koornneef and Pieterse 2008).

\section{RESULTS}

The $2 \mathrm{~b}$ protein enhances transcriptional responses to $\mathrm{SA}$.

SA or control solutions were sprayed on nontransgenic Arabidopsis plants or transgenic plants constitutively expressing the $2 b$ gene of Fny-CMV. Microarray analyses revealed that expression of only five transcripts, including $A R F 4$ and $A G O 2$, was altered significantly $(P \leq 0.05)$ in $2 b$-transgenic plants (Table 1). Thus, in the absence of any chemical treatment, transgenic expression of the $2 \mathrm{~b}$ protein induced few detectable changes in the transcriptome. This is in accordance with our previous study, which showed that, in the absence of treatment, the $2 \mathrm{~b}$ protein caused only limited changes in gene expression, and that $A R F$ were among those genes exhibiting changed expression levels (Lewsey et al. 2007).

Consistent with previous studies (Maleck et al. 2000), SA triggered major alterations in the transcriptome of nontransgenic plants (Table 1). Remarkably, and despite its documented role in the subversion of SA-induced resistance (Ji and Ding, 2001), $2 \mathrm{~b}$ expression enhanced rather than diminished the transcriptome's response to SA. Although, in nontransgenic plants, 766 transcripts were significantly altered in abundance by SA treatment $(P<0.05)$, in $2 b$-transgenic plants, SA significantly altered abundance of 1,159 transcripts (Table 1; Supplementary Spreadsheets S1 and S2). Among transcripts affected significantly by SA treatment in nontransgenic plants, $62 \%$ were also affected significantly in SA-treated $2 b$-transgenic plants, which was a statistically significant overlap $(P<0.00001)$. $P R 1$, a well-characterized marker of SA treatment, was the most significantly induced transcript in both $2 b$-transgenic and nontransgenic plants treated with SA. Every transcript that overlapped between these datasets also responded in the same manner to SA treatment in nontransgenic and $2 b$-transgenic plants (i.e., induced in both or repressed in both). Additionally, only 19 transcripts showed significant differences $(P<0.05)$ in their responses to SA between $2 b$-transgenic and nontransgenic plants (Table 1; Supplementary Spreadsheet S3). Three of these encoded mitochondrial electron transport components, which may be significant, given the role of mitochondrial signaling in SA-induced virus resistance (Singh et al. 2004). Although these data indicate that, paradoxically, expression of the $2 \mathrm{~b}$ protein increases the influence of SA on the transcriptome, they are also consistent with a role for $2 \mathrm{~b}$ in subverting SA-regulated antiviral effects.

Table 1. Salicylic acid (SA)-regulated gene expression in nontransgenic and $2 b$-transgenic plants ${ }^{\mathrm{a}}$

\begin{tabular}{lc}
\hline Comparison & Number of transcripts ${ }^{\mathbf{b}}$ \\
\hline NT SA vs. NT control & 766 \\
2b SA vs. 2b control & 1,159 \\
2b SA vs. NT SA & 19 \\
2b control vs. NT control & 5 \\
\hline a Two-way comparisons of transcript expression data from microarray \\
experiments where RNA had been extracted from control-treated or SA- \\
treated nontransgenic (NT) and 2b-transgenic $(2 \mathrm{~b})$ plants in order to \\
identify genes that were differentially regulated $(P<0.05)$. \\
b Number of significantly differentially regulated transcripts.
\end{tabular}

Transcripts selected from among the 19 found in microarray experiments to be expressed differentially in SA-treated nontransgenic versus $2 b$-transgenic plants were analyzed further by RNA blotting and phosphoimager quantification (Fig. 1). These were AT4G12970 (function unknown), AGO2, AT3G16530 (lectin-like protein), and AT2G15050 (lipid-transfer protein PR-14) (Sels et al. 2008). Levels of three transcripts ( $A G O 2, A T 3 G 16530$, and AT2G15050) were increased in control-treated $2 b$-transgenic plants, relative to control-treated nontransgenic plants (Fig. 1), confirming the microarray results. Furthermore, in $2 b$-transgenic plants, two of the four transcripts examined (AT2G15050 and AT4G12970) exhibited more extreme changes in steady-state abundance in response in SA. $A G O 2$ was upregulated by SA treatment in both nontransgenic and $2 b$-transgenic plants but accumulated to higher levels in $2 b$-transgenic plants, regardless of whether or not they had been treated with SA (Fig. 1). The results demonstrated that transgenic expression of $2 \mathrm{~b}$ protein interferes both with basal expression of SA-regulated genes and transcriptional responses to exogenous SA. Database interrogation revealed that homologous sRNAs exist for 15 of the 19 SA-responsive transcripts (Supplementary Spreadsheet S4), indicating that they are likely to be under RNA-silencing regulation.

\section{The 2b protein facilitates CMV-induced SA biosynthesis.}

$\mathrm{SA}$ accumulation was measured in nontransgenic and $2 b$ transgenic plants following infection with Tobacco mosaic virus (TMV), CMV, or CMV $\Delta 2$ b. CMV $\Delta 2 \mathrm{~b}$ is a deletion mutant of CMV lacking the $2 \mathrm{~b}$ protein gene but able to infect plants and spread systemically (Ryabov et al. 2001; Soards et al. 2002; Lewsey et al. 2009b). In Arabidopsis ecotype Col-0, CMV and TMV are both compatible pathogens, both spread systemically, and neither elicits any obvious resistance responses (such as the production of hypersensitive response lesions). As expected, TMV did not trigger any increase in SA above the levels seen in mock-inoculated plants. However, by 10 days postinoculation (dpi), systemic infection with CMV had caused SA levels to rise by two- to threefold over those seen in mock-inoculated or TMV-infected plants (Fig. 2A). It should be noted that there was an increase over time in basal SA accumulation (compare values in mock-inoculated plants at 3 versus $10 \mathrm{dpi}$ ) that is consistent with previous data showing that, in Arabidopsis, SA levels rise over the development of this plant (Morris et al. 2000; Cameron and Zaton 2004).

Increased SA accumulation in CMV-infected plants was not seen until 10 dpi (Fig. 2A). However, CMV spreads systemically by 6 dpi in Arabidopsis (Lewsey et al. 2009b), which is prior to the detected increase in SA accumulation (Fig. 2A). The $2 b$ protein is not itself an elicitor of increased SA biosynthesis; infection with CMV $\Delta 2 \mathrm{~b}$ triggered increased SA biosynthesis in $2 b$-transgenic plants but did not affect SA levels in nontransgenic plants, and SA levels in mock-inoculated $2 b$ transgenic plants remained unchanged compared with wildtype plants (Fig. 2B). Thus, it appears likely that the $2 \mathrm{~b}$ protein facilitates elicitation of SA biosynthesis by another viral gene product or products. Interestingly, SA did not accumulate to the same level in $2 b$-transgenic plants infected with either CMV or CMV $\triangle 2 b$ as it did in CMV-infected nontransgenic plants (Fig. 2B). This may indicate that constitutive expression of $2 \mathrm{~b}$ protein in the transgenic plants habituates the SA signaling pathway, impairing its ability to respond to viral infection, and correlating with increased basal expression of SA-responsive transcripts (Fig. 1).

The induction of SA biosynthesis in CMV-infected plants was further investigated. The major SA biosynthetic pathway in plants generates SA from isochorismate (Wildermuth et al. 2001; Garcion et al. 2008). This requires the isochorismate 
synthase (ICS), which converts chorismate to isochorismate (Wildermuth et al. 2001; Garcion et al. 2008). ICS1 is induced by pathogen infection, and null mutants in the gene encoding ICS1 have drastically reduced ability to synthesize SA (Wildermuth et al. 2001; Garcion et al. 2008). The ICS1 promoter was cloned from Arabidopsis into a binary vector upstream of a $\beta$-glucuronidase (GUS) gene from Escherichia coli, and the construct transformed into Arabidopsis. The expression pattern of the reporter protein under control of the ICS1 promoter was monitored in mock-, CMV-, and TMV-inoculated plants by histochemical staining for GUS activity. Infection with CMV induced high levels of GUS activity by 14 dpi in systemically infected, noninoculated tissue in two independent transgenic lines (Supplementary Fig. S1). Contrastingly, in mock-inoculated and TMV-infected plants, GUS activity was not induced and was only detected at very low levels. These data indicate that the activity of the ICSI promoter is induced by CMV but not by TMV infection.

\section{The $2 \mathrm{~b}$ protein extensively disrupts}

JA-regulated transcription.

Nontransgenic and $2 b$-transgenic Arabidopsis plants were sprayed with methyljasmonic acid (MeJA) or a control solution. Microarray analyses revealed, unexpectedly, that $2 b$ gene expression had a more striking effect on JA-regulated gene expression than it did on SA-regulated gene expression (Table 2; Supplementary Spreadsheets S5 and S6). Whereas, in nontransgenic plants, MeJA affected the expression of
1,268 transcripts, in 2b-transgenic plants, only 4 were as significantly $(P<0.05)$ altered in expression by this chemical (Table 2). Further bioinformatic analysis confirmed that approximately $90 \%$ of the 1,268 JA-responsive transcripts were less responsive to MeJA in $2 b$-transgenic plants (genes with expression ratios of $>0$ but $<1$ ) (Fig. 3 ). However, the $2 \mathrm{~b}$ protein's effects on the expression of individual plant genes varied over a continuum ranging from abolition to mild inhibition. Remarkably, 100 genes that are either induced or repressed by MeJA treatment in nontransgenic plants exhibited the opposite of their normal behavior in $2 b$-transgenic plants (i.e., genes with expression ratios that are <0) (Fig. 3). These analyses also revealed that, of the 246 transcripts that exhibited differential expression between MeJA-treated $2 b$ transgenic and nontransgenic plants (Table 2), the majority $(59.8 \%)$ had expression ratios of $<0.5$.

RNA blot analysis of selected JA-regulated transcripts confirmed that transcriptional responses to MeJA treatment were altered in $2 b$-transgenic plants (Fig. 3; Supplementary Table $\mathrm{S} 1)$. Three MeJA-inducible transcripts-TERPENE SYNTHASE 10 (TPS10), THIONIN 2.1 (THI2.1), and AT3G55290 (selected from analyses shown in Figure 3)-were examined in detail to validate the DNA microarray analyses. The microarray analyses had indicated that, in $2 b$-transgenic plants, the ability of MeJA to induce increases in TPS10, AT3G55290, and THI2.1 transcript levels was inhibited. The behavior of these transcripts in response to MeJA treatment was compared between nontransgenic plants and plants of four independent

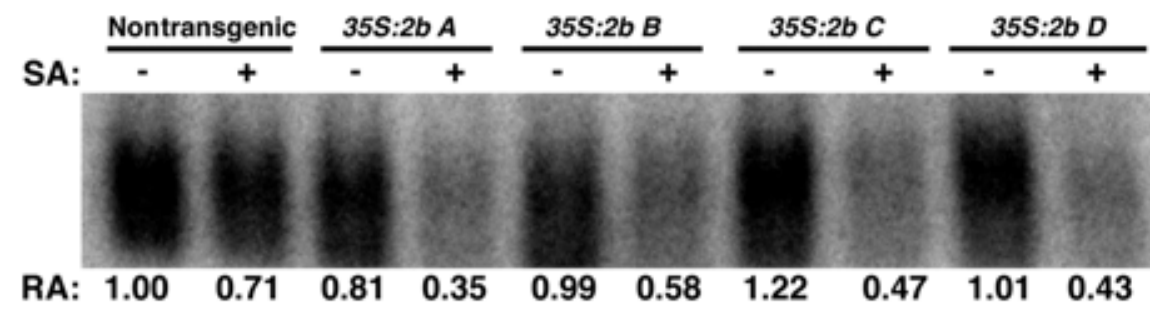

AT4G12970
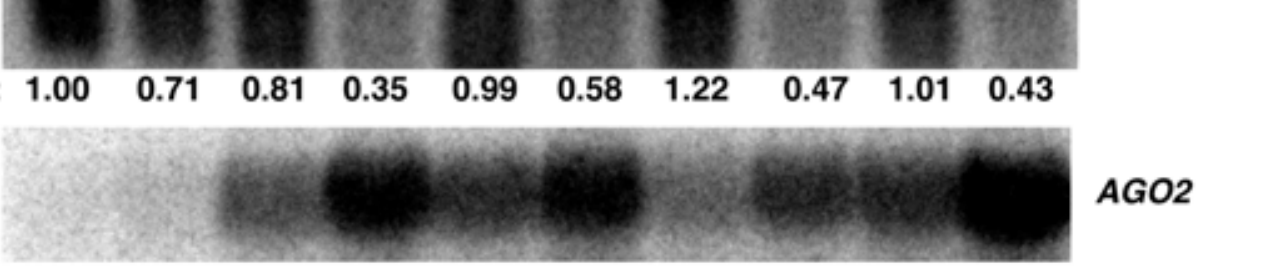

AGO2

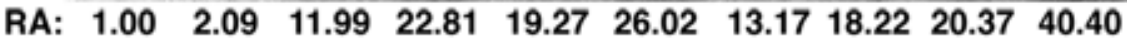

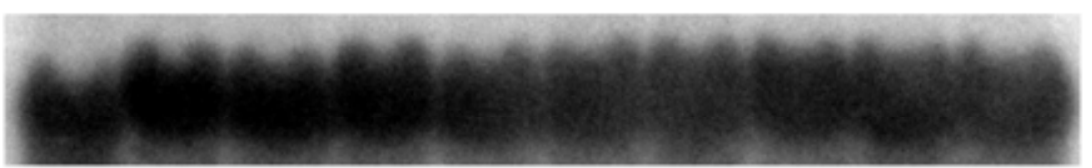

18S rRNA

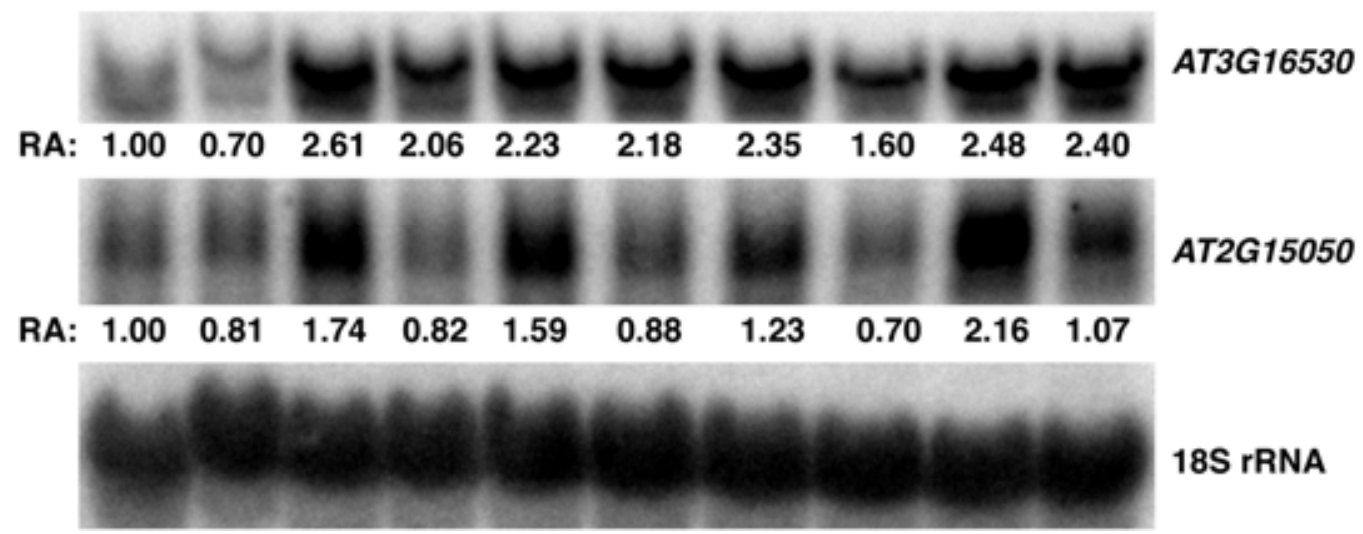

Fig. 1. Salicylic acid (SA)-regulated gene expression is modified in $2 b$-transgenic plants. RNA blot analysis of steady-state transcript accumulation for four plants genes in four independent $2 b$-transgenic Arabidopsis lines ( $A$ to $D$ ) confirmed microarray analyses showing that $2 \mathrm{~b}$ affects the responses of these genes to $1 \mathrm{mM}$ SA. Transcripts and $18 \mathrm{~S}$ rRNA were detected using complementary ${ }^{32}$ P-labeled DNA probes. RA: relative accumulation of transcripts (quantified by phosphorimage analysis of bound radioactivity) normalized to $18 \mathrm{~S}$ rRNA accumulation. 
$2 b$-transgenic lines, using RNA blotting and quantification by phosphorimage analysis (Fig. 4), and independently confirmed by quantitative reverse-transcription polymerase chain reaction (Q-RT-PCR) (Supplementary Table S2). In all four $2 b$-transgenic lines, the responses of the transcripts were consistent with the microarray results. As a further confirmation, the transcriptional response of TPS10 to wounding was examined,
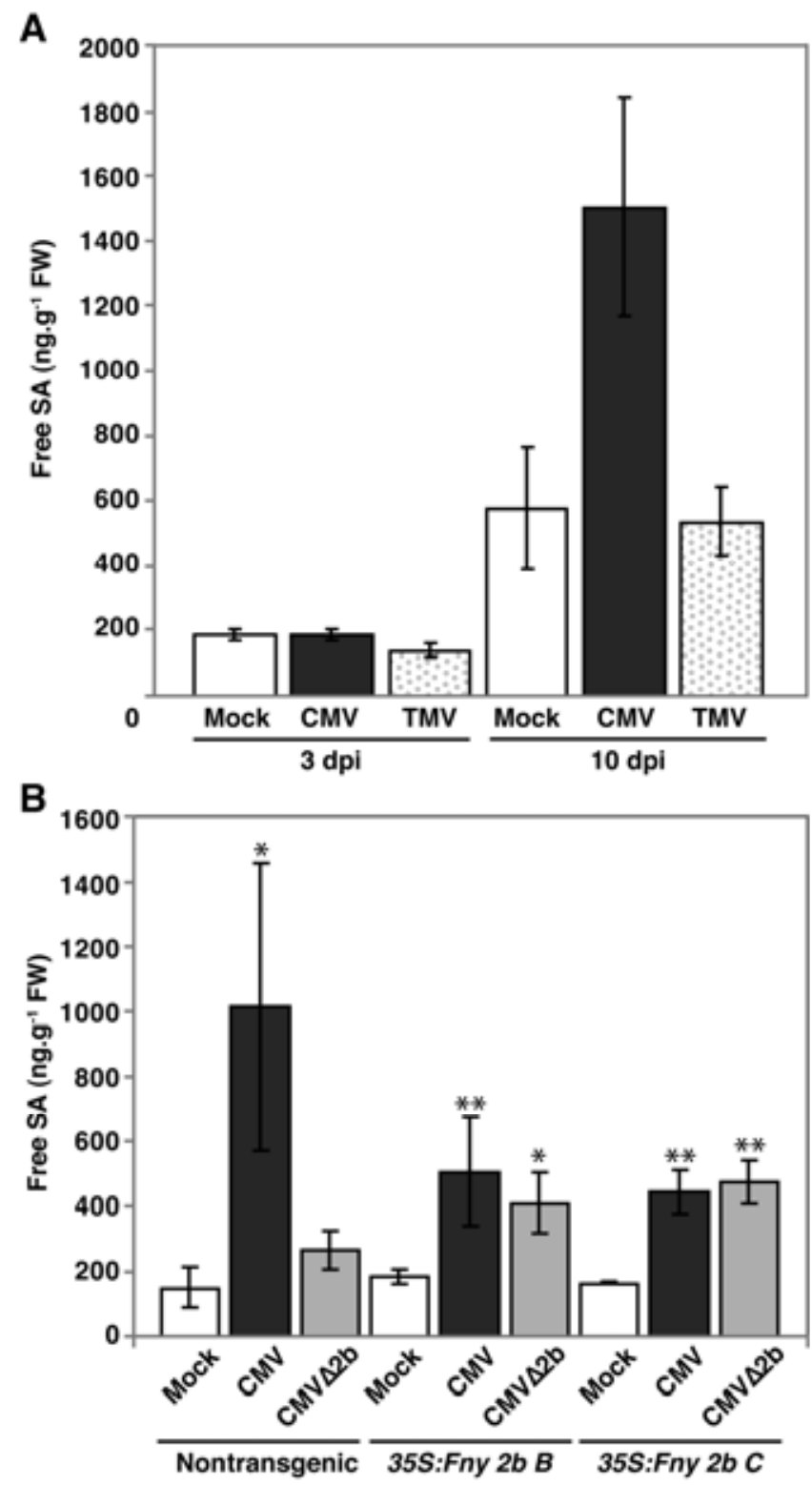

Fig. 2. Cucumber mosaic virus (CMV) infection triggers increased biosynthesis of salicylic acid (SA). A, SA levels (measured by high-performance liquid chromatography) were elevated in nontransgenic Arabidopsis plants 10 days postinoculation (dpi) with CMV but did not change significantly after inoculation with Tobacco mosaic virus (TMV) or mock inoculation. B, SA levels in nontransgenic plants were not significantly changed by infection with CMV $\Delta 2 \mathrm{~b}$, a $2 b$ gene deletion mutant, $14 \mathrm{dpi}$. In contrast, infection with CMV or CMV $\Delta 2 \mathrm{~b}$ increased SA levels in plants of two independent $2 b$-transgenic lines (35S:Fny $2 b B$ and 35S:Fny $2 b C$ ), measured 14 dpi. Statistically significant differences (from Student's $t$ test) are indicated by $*(P \leq 0.05)$ and $* *(P \leq 0.01)$. These were calculated within each plant line (nontransgenic, 35S:Fny $2 b$ $B$, or $35 S: F n y 2 b C$ ) compared with the mock-inoculated plants of that line. SA accumulation was significantly higher $(P \leq 0.05)$ in $\mathrm{CMV}$ infected nontransgenic plants compared with CMV-infected $2 b$-transgenic plants (comparison used pooled data of CMV-infected 35S:Fny $2 b$ $B$ and $C$ plants, and is not illustrated). FW: fresh weight. using Q-RT-PCR to measure transcript abundance up to $4 \mathrm{~h}$ postwounding. Wounding of plants stimulates the JA signaling pathway, resulting in upregulation of JA responsive transcripts (Devoto et al. 2005). The abundance of the TPS10 transcript increased to approximately twofold greater in nontransgenic plants compared with $2 b$-transgenic plants by $2 \mathrm{~h}$ postwounding, and remained so at 4 hours postwounding (Supplementary Fig. S2).

The $2 \mathrm{~b}$ protein disrupts sRNA-regulated mRNA turnover (Zhang et al. 2006; Lewsey et al. 2007). Furthermore, sRNAdirected RNA degradation pathways play an important role in the regulation of JA-regulated gene expression (Pandey et al. 2008). We screened the sequences of the 1,268 JA-responsive transcripts identified in nontransgenic plants for regions of complementarity to previously identified Arabidopsis sRNAs (Rajagopalan et al. 2006) and found that approximately 55\% of these transcripts possess potential sRNA target sites (Supplementary Spreadsheet S7).

\section{CMV infection disrupts transcriptional responses to MeJA but does not affect JA biosynthesis.}

After MeJA treatment, the relative accumulation of three MeJA-responsive transcripts selected from the microarray analyses was clearly inhibited in CMV-infected plants but not in plants infected with CMV $\Delta 2 \mathrm{~b}$ (Fig. 5). These transcripts were AT3G55290 (encoding a short [polypeptide]-chain dehydrogenase/reductase), LOX2 (encoding LIPOXYGENASE 2), and TPS10. MeJA-induced expression of another JA-responsive transcript (CYP79B2, encoding an enzyme of glucosinolate biosynthesis) was not affected markedly by the presence of CMV (Fig. 5). This behavior is consistent with the microarray data showing that the expression of $2 b$ did not inhibit the induction of $C Y P 79 B 2$ by MeJA (Supplementary Spreadsheet $\mathrm{S} 8$ ). Thus, the $2 \mathrm{~b}$ protein, regardless of whether it is expressed from a transgene or during a CMV infection, selectively inhibits JA-responsive gene expression.

CMV $\Delta 2$ b infection caused a small but detectable inhibition in the response of certain JA-regulated transcripts to MeJA (TPS10, CYP79B2, and LOX2) (Fig. 5). However, this effect was not as strong as that seen in either CMV-infected plants or $2 b$-transgenic plants, and relative accumulation data obtained by phosphoimager analysis indicated that the degree of inhibition of MeJA-responsive gene expression did not correlate with the relative accumulation of CMV and CMV $\Delta 2 \mathrm{~b}$ (Fig. 5). In combination, our results with virus-infected plants and $2 \mathrm{~b}-$ transgenic plants indicate that the $2 \mathrm{~b}$ protein strongly suppresses MeJA-induced transcriptional responses during CMV infection but suggest that another CMV gene product (or products) may exert additional inhibitory effects on MeJA-induced gene expression.

CMV infection inhibits expression of $L O X 2$, which encodes a lipoxygenase with a role in JA biosynthesis (Bell et al. 1995). To investigate whether CMV infection or the $2 \mathrm{~b}$ protein inhibit JA production, we measured JA levels in plant tissue. We found

Table 2. Effects of methyljasmonic acid (MeJA) on gene expression in nontransgenic and $2 b$-transgenic plants ${ }^{\mathrm{a}}$

\begin{tabular}{lc}
\hline Comparison & Number of transcripts $^{\mathbf{b}}$ \\
\hline NT MeJA vs. NT control & 1,268 \\
2b MeJA vs. 2b control & 4 \\
2b MeJA vs. NT MeJA & 246 \\
\hline
\end{tabular}

a Two-way comparisons of transcript expression data from microarray experiments where RNA had been extracted from control-treated or MeJA-treated nontransgenic (NT) and $2 b$-transgenic (2b) plants in order to identify genes that were significantly differentially regulated $(P<$ $0.05)$.

${ }^{\mathrm{b}}$ Number of significantly differentially regulated transcripts. 
that, in nontransgenic and $2 b$-transgenic plants, mechanical wounding, a potent inducer of JA biosynthesis, was equally effective at triggering an increase in JA levels (Fig. 6A). However, we found that there were no significant effects on JA lev- els that could be attributed to infection with either CMV or the deletion mutant $\mathrm{CMV} \Delta 2 \mathrm{~b}$ in nontransgenic or $2 b$-transgenic plants (Fig. 6B). Thus, JA biosynthesis is not inhibited by CMV infection or the $2 \mathrm{~b}$ protein.

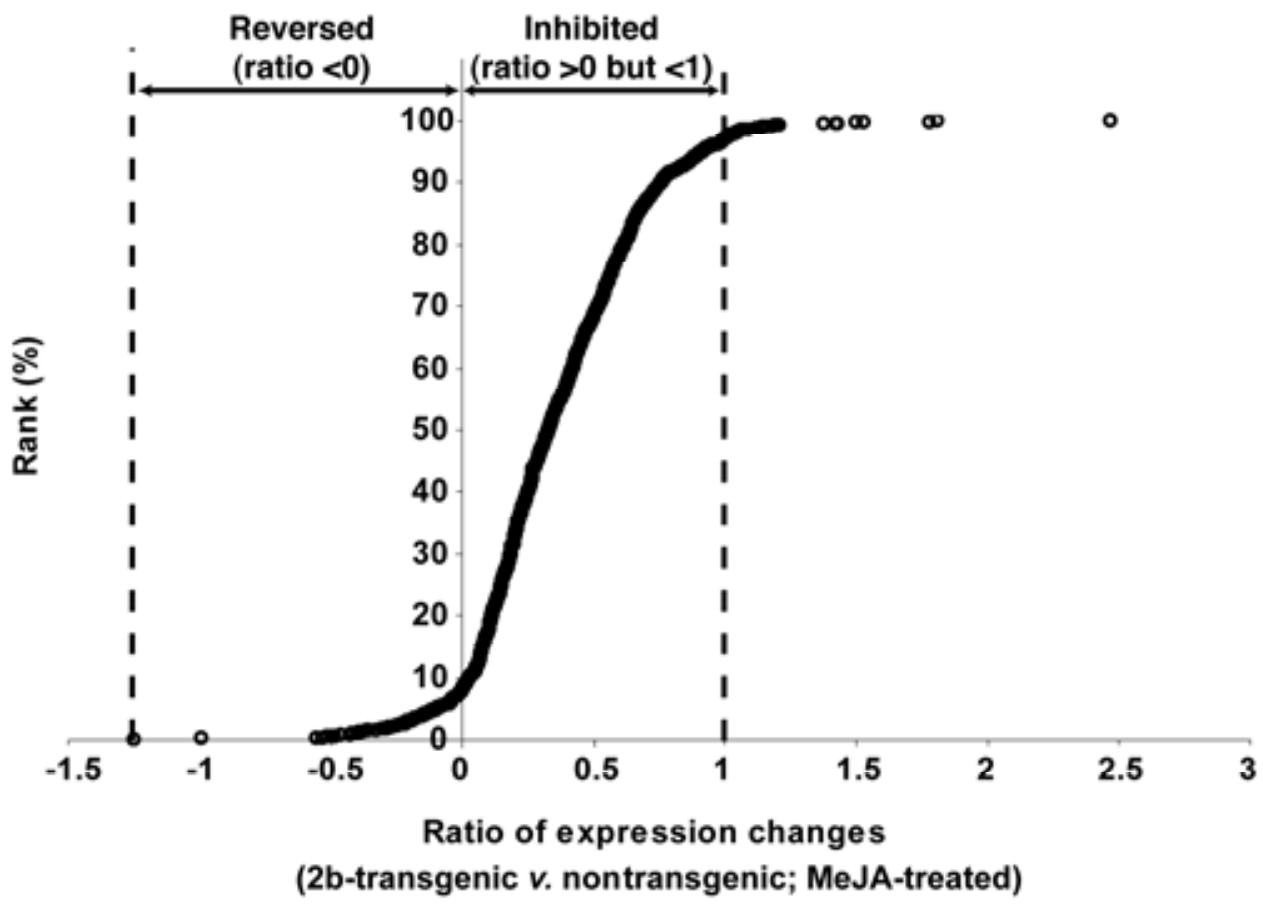

Fig. 3. Transgenic expression of $2 b$ protein caused broad disruption of the transcriptional response to methyljasmonic acid (MeJA) treatment. The extent of disruption of MeJA-induced changes in transcript accumulation in $2 b$-transgenic plants varied between jasmonic-acid-responsive genes. MeJA treatment induced significant $(P<0.05)$ changes in expression of 1,268 transcripts in nontransgenic plants. The degree to which expression of each individual transcript was altered by MeJA treatment in $2 b$-transgenic versus nontransgenic plants was calculated from averaged, normalized expression values (EV) and expressed as a ratio using the following formula: Ratio of expression change $=\left(\mathrm{EV}_{2 \mathrm{~b} \text { MeJA-treated }}-\mathrm{EV}_{\text {nontransgenic control }}\right) /\left(\mathrm{EV}_{\text {nontransgenic MeJA-treated }}-\mathrm{EV}_{\text {nontransgenic }}\right.$ control). A ratio of 1 indicates that a transcript's response to MeJa was unaffected by $2 \mathrm{~b}$, a ratio $>0$ but $<1$ indicates an inhibited response ( $90 \%$ of transcripts), and a negative ratio indicates that the response was reversed (7.9\% of transcripts). Transcripts were ranked from lowest to highest ratio and plotted as a cumulative distribution function, with the rank scaled as a percentage of the total number of transcripts.

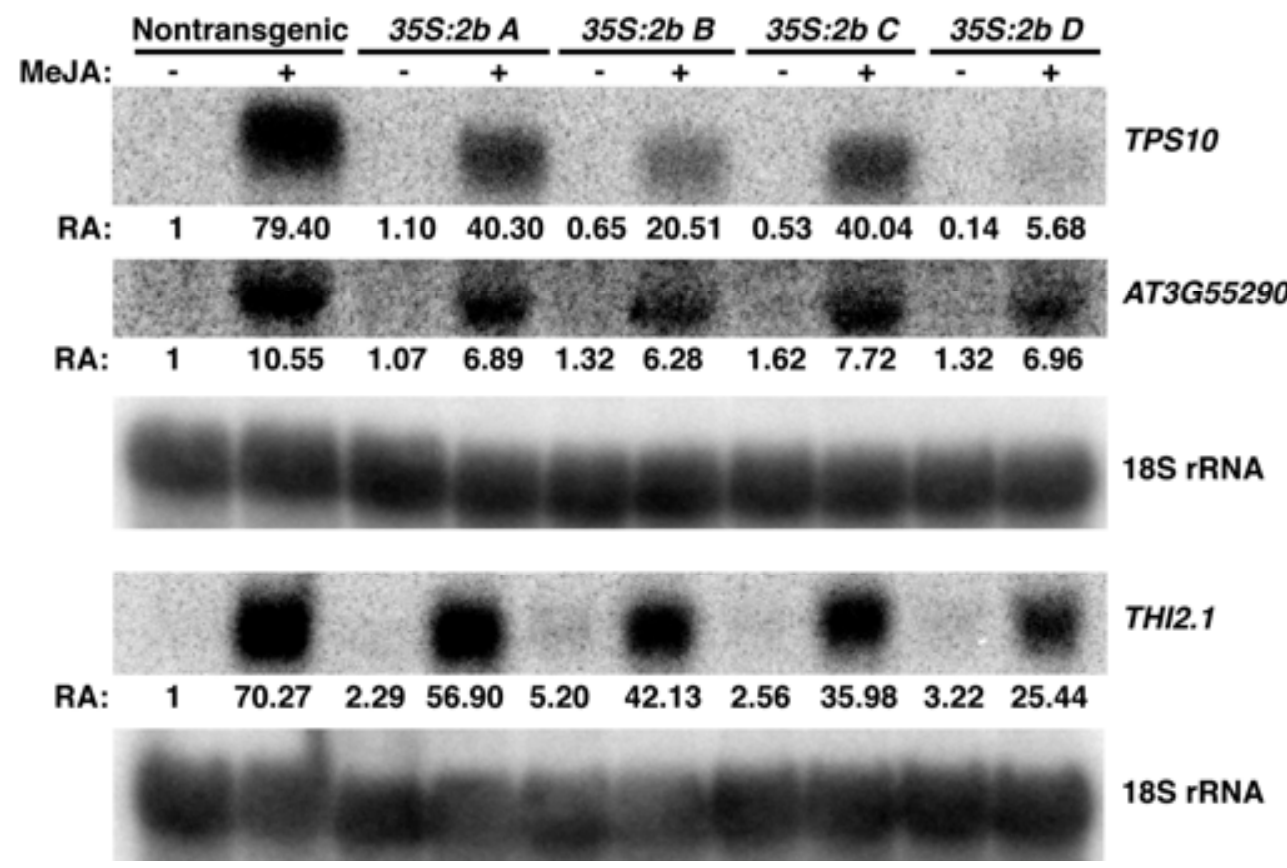

Fig. 4. Methyljasmonic acid (MeJA)-induced changes in gene expression are inhibited in $2 b$-transgenic plants. RNA blotting for three jasmonic-acidresponsive transcripts (TPS10, THI2.1, and AT3G55290) in MeJA-treated or nontreated plants of four independent 2b-transgenic plant lines (35S:Fny 2b A$D$ ) confirmed microarray analyses. Transcripts and $18 \mathrm{~S}$ rRNA were detected using complementary ${ }^{32} \mathrm{P}$-labeled DNA probes. RA: relative accumulation of transcripts (quantified by phosphorimage analysis of bound radioactivity) normalized to $18 \mathrm{~S}$ rRNA accumulation. 


\section{DISCUSSION}

The CMV 2 b protein was already known to inhibit RNA silencing and subvert SA-induced virus resistance (Brigneti et al. 1998; Ji and Ding 2001). However, we now show that it also interferes with JA-dependent signaling but not JA biosynthesis, and that its effects on SA-mediated gene expression and SA biosynthesis are complex. Remarkably, the $2 \mathrm{~b}$ protein inhibits a very high proportion of the transcript abundance changes normally induced by MeJA treatment and, in some cases, even reverses genes' normal responses.

In the absence of treatment, the $2 \mathrm{~b}$ protein affects significantly the abundance of very few transcripts. This is consistent with our previous work on $2 b$-transgenic plants (Lewsey et al. 2007) and may indicate the $2 \mathrm{~b}$ protein is specialized for hor- mone-signaling disruption. However, it may be due to the substantially lower $2 \mathrm{~b}$ protein expression levels in the transgenic lines examined compared with expression in CMV-infected plants (Lewsey et al. 2007).

The $2 \mathrm{~b}$ protein might disrupt hormone signaling by two potential mechanisms. The first is RNA silencing. The $2 b$ protein has direct or indirect effects on at least two AGO family proteins, which are the only known components of the Arabidopsis RISC (Baumberger and Baulcombe 2005; Vaucheret 2008). In our study, the $A G O 2$ mRNA was significantly upregulated in control-treated $2 b$-transgenic plants (Fig. 1). This probably occurred because the $2 \mathrm{~b}$ protein inhibits AGO1 activity, interfering with miRNA-directed cleavage of cellular mRNAs (Zhang et al. 2006). It is likely that this disrupts cleavage of the $A G O 2 \mathrm{mRNA}$ by MIR403, an miRNA that targets it (Allen et al. 2005), thereby

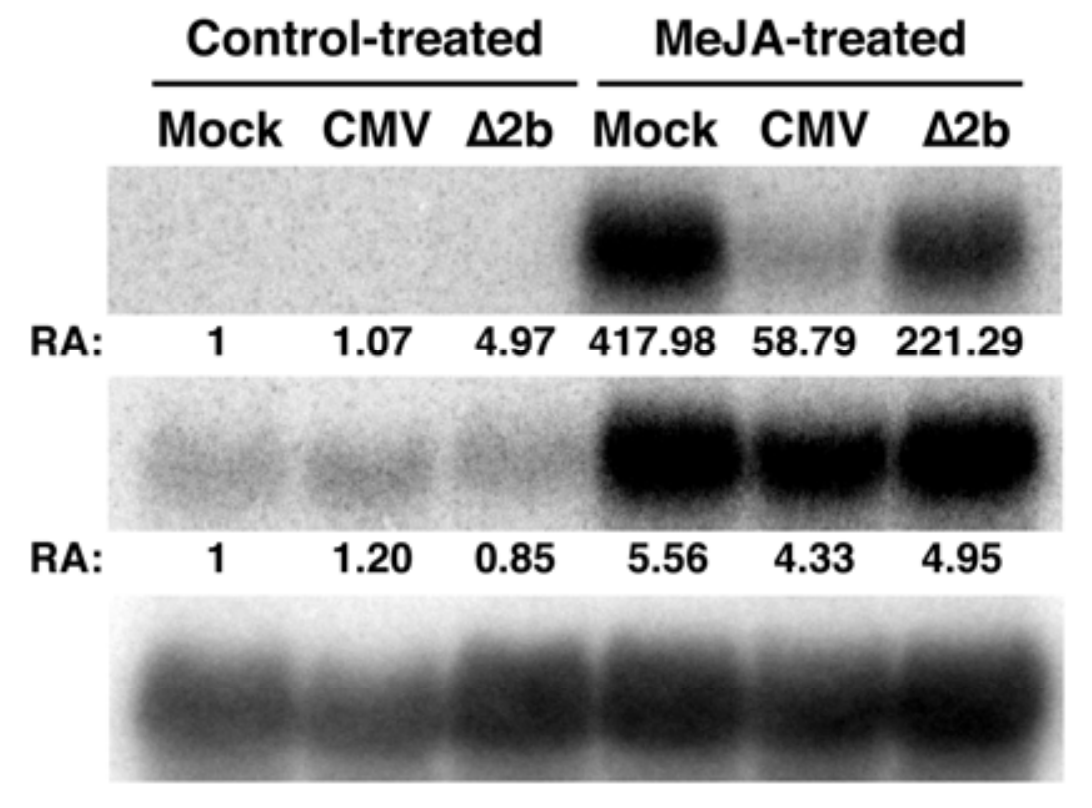

TPS10

CYP79B2

18S rRNA

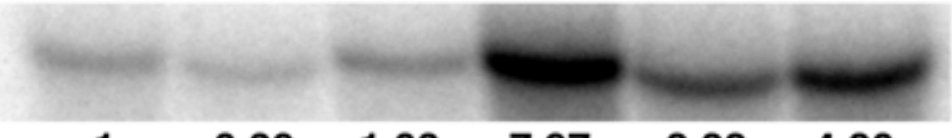

LOX2

RA:

$1 \quad 0.39$

1.03

7.97

2.22

4.80

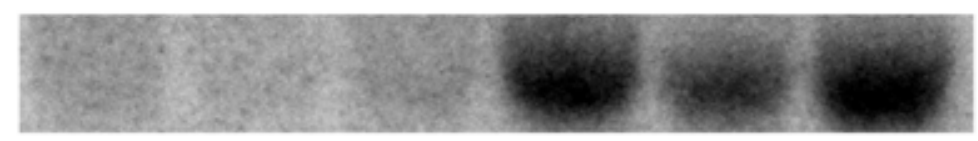

AT3G55290

RA:

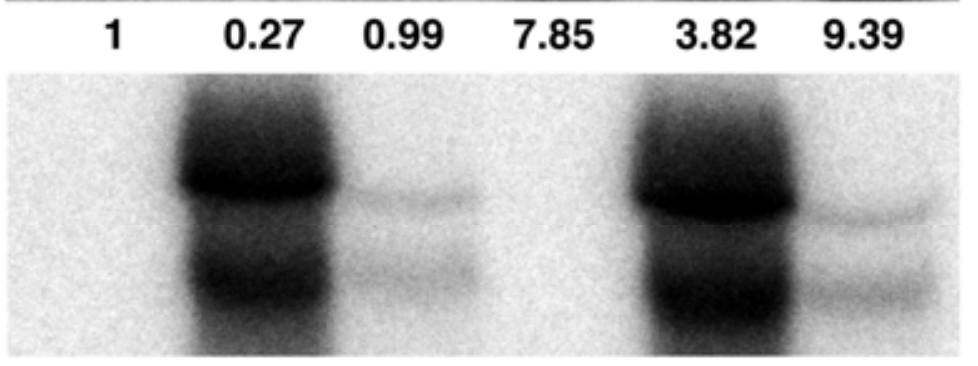

CMV RNA

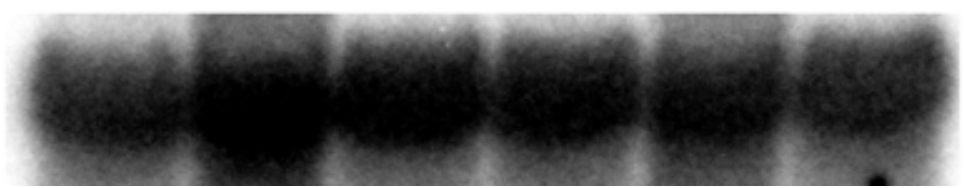

18S rRNA

Fig. 5. Infection with wild-type Cucumber mosaic virus (CMV) but not the $2 b$ deletion mutant CMV $\Delta 2 \mathrm{~b}$ inhibits methyljasmonic acid (MeJA)-induced changes in gene expression. Total RNA was extracted from mock-inoculated or CMV- or CMV $\Delta 2 \mathrm{~b}$-infected plants sprayed with $250 \mu \mathrm{M}$ MeJA or a control solution. TPS10, CYP79B2, LOX2, AT3G55290, 18S rRNA, and CMV-specific transcripts were detected by RNA blot hybridization using appropriate ${ }^{32} \mathrm{P}-$ labeled DNA probes. RA: relative accumulation of transcripts (quantified by phosphorimage analysis of bound radioactivity) normalized to 18S rRNA accumulation. 
increasing its accumulation. Furthermore, the $2 \mathrm{~b}$ protein may have additional effects due, for example, to its sRNA-binding ability (Goto et al. 2007). Hence, the $2 \mathrm{~b}$ protein might disrupt JA- and SA-mediated defensive signaling by interfering with regulation of gene expression by RNA silencing. We speculate that, if $\mathrm{AGO} 2$ negatively regulates JA-responsive transcription and positively regulates SA-responsive transcription, the inhibition of AGO1 activity by $2 b$ may partly explain the effects of this VSR on JA- and SA-regulated gene expression. Our proposal is supported by the finding that RDR1, another component of RNA silencing, affects the expression of many JA-regulated genes in Nicotiana attenuata (Pandey et al. 2008). Notably, the $2 \mathrm{~b}$ protein is known to affect RDR1 activity in Arabidopsis (Diaz-Pendon et al. 2007), which might provide an additional mechanism by which $2 \mathrm{~b}$ interferes with JA-regulated signaling.

The second potential mechanism by which the $2 \mathrm{~b}$ protein may interfere with JA signaling is via SA signaling itself. There is strong crosstalk between SA and JA signaling, which may be either antagonistic or synergistic depending on the specific circumstances by which signaling is induced (Schenk et al. 2000; van Wees et al. 2000; Spoel et al. 2003). The SA biosynthesis facilitated or primed by the $2 \mathrm{~b}$ protein during viral infection may act antagonistically to suppress JA signaling.

Although CMV $\Delta 2$ b infection had a modest effect on JAregulated gene expression, it is unlikely that differences in viral accumulation explain the relative degrees to which CMV and CMV $\Delta 2 \mathrm{~b}$ suppressed MeJA-responsive gene expression. This is because, in $2 b$-transgenic plants, the $2 \mathrm{~b}$ protein by itself was able to suppress MeJA-responsive gene expression. Also, there was no correlation between CMV and CMV $\Delta 2 \mathrm{~b}$ accumulation and the relative accumulation values of the plant mRNAs examined (Fig. 5). Nevertheless, the data suggest that the $2 \mathrm{~b}$ protein may not be the only CMV-encoded factor that inhibits JA responses. Recently, the pathogenicity factor encoded by a geminiviral satellite DNA was found to inhibit expression of five JA-regulated genes (Yang et al. 2008) and the potyviral silencing suppressor HCPro was shown to interfere with JA-regulated transcript abundance (Endres et al. 2010), suggesting that gene products of other viruses can affect JAmediated signaling.

The $2 \mathrm{~b}$ protein did not inhibit expression of most SA-regulated genes but, in $2 b$-transgenic plants, a number of genes that are normally unaffected by SA became SA responsive. We also found that SA biosynthesis was induced during CMV infection, as was the activity of the ICS1 promoter, which controls expression of a key enzyme for SA biosynthesis. SA production and SA-induced gene expression are closely associated with resistance to local and systemic virus infection (Singh et al. 2004; Lewsey et al. 2009a). Typically, SA production is not enhanced by systemic infection of susceptible host plants with compatible viruses, such as in TMV-infected Arabidopsis (Fig. 2) or TMV-susceptible tobacco (Malamy et al. 1990). Various studies have shown that CMV systemic movement is inhibited by treatment of plants with exogenous SA or triggering of endogenous SA biosynthesis prior to inoculation (Naylor et al. 1998; Ji and Ding 2001; Mayers et al. 2005), and that the 2b protein subverts SA-induced resistance to CMV replication and local movement (Ji and Ding 2001). Thus, the enhancement of SA-induced gene expression and facilitation of SA biosynthesis by the $2 \mathrm{~b}$ protein appears paradoxical. However, the CMV-induced increase in SA levels occurs relatively slowly, when systemic movement of the virus to all parts of the plant will have already taken place. Therefore, the inhibitory effect of SA on systemic movement will be irrelevant by this time and the counter-defensive action of the $2 \mathrm{~b}$ protein will subvert any effects of SA on CMV replication or local movement in systemically infected tissues (Naylor et al. 1998; Ji and Ding
2001; Murphy and Carr 2002). Interestingly, in some hosts, CMV titers vary or "cycle" over time (Gal-On et al. 1996) and it is possible that this effect on the dynamics of virus infection may be a side-effect of CMV-induced SA biosynthesis.

Increased expression of SA-responsive genes has been seen previously in CMV-infected Arabidopsis (Whitham et al. 2003). The ability of the $2 \mathrm{~b}$ protein to facilitate increased SA biosynthesis during CMV infection may explain this. CMV-induced production of SA was lower in $2 b$-transgenic plants. This implies that, whereas expression of $2 b$ during a viral infection primes the elicitation of SA biosynthesis, constitutive expression of the $2 \mathrm{~b}$ protein habituates the system regulating SA biosynthesis, making it less responsive. This might explain, at least in part, why $2 b$-transgenic Arabidopsis plants have been shown to be more susceptible to CMV and CMV $\Delta 2 \mathrm{~b}$ infection than nontransgenic plants (Lewsey et al. 2009b).

The benefit to CMV of inhibiting JA-mediated signaling and priming SA-mediated signaling is not immediately obvious. One possibility is that the $2 \mathrm{~b}$ protein is suppressing a JA-dependent mechanism of resistance to CMV. Generally, JA is not considered to be an inducer of virus resistance (Ton et al. 2002). However, JA-dependent resistance to CMV has been observed in plants exposed to beneficial root-colonizing bacteria (Raupach et al. 1996; Zehnder et al. 2000), and the 2b protein may help to suppress this.

A second, more likely, potential benefit of suppressing JA signaling relates to transmission of CMV by its aphid vectors.

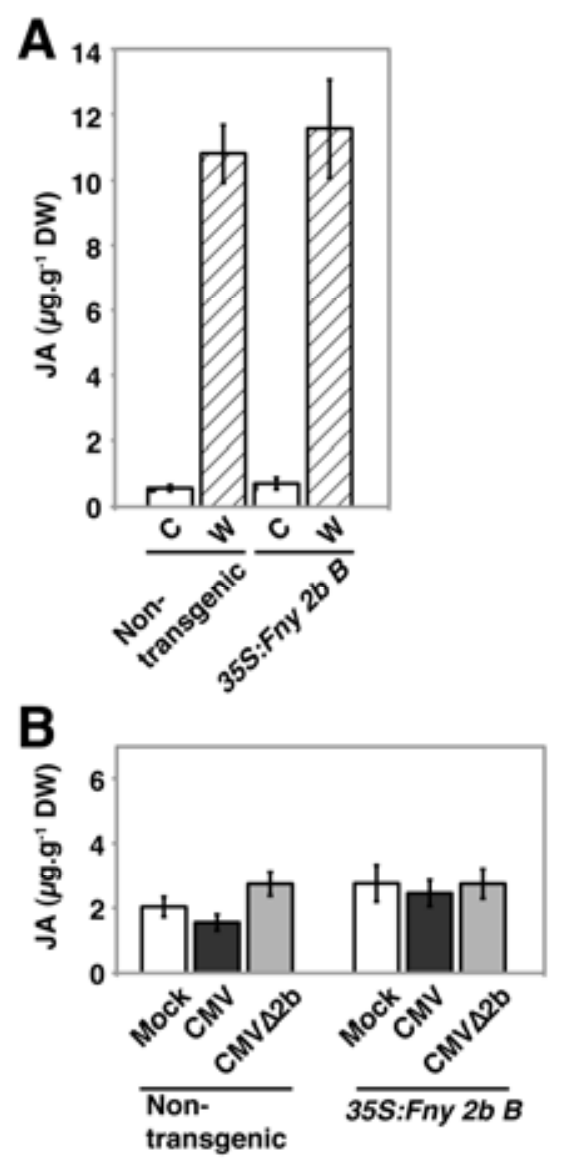

Fig. 6. Cucumber mosaic virus (CMV) 2b protein does not alter biosynthesis of jasmonic acid (JA). A, JA levels (measured by reverse-phase liquid chromatography coupled electrospray ionization/tandem mass spectroscopy) after wounding (W) were not altered in nontransgenic or $2 b$-transgenic plants. B, Furthermore, basal levels of JA were not markedly altered in nontransgenic or $2 b$-transgenic plants at 14 days postinoculation with either CMV or CMV $\Delta 2$ b. C: nonwounded control plants. DW: dry weight. 
CMV, like many plant-infecting viruses, is aphid transmissible (Palukaitis and Garcia-Arenal 2003; Canto et al. 2009). JA stimulates resistance to insects, including aphids (Ellis et al. 2002; Zarate et al. 2007; Howe and Jander 2008; Koornneef and Pieterse 2008; Rohwer and Erwin 2008), whereas SA favors infestation of plants by insects that have piercing-sucking mouthparts (stylets) (Zarate et al. 2007). Infestation by aphids or whiteflies, which are both stylet feeders, induces localized SA biosynthesis and SA-induced gene expression, potentially suppressing JA-regulated defense via JA/SA crosstalk (De Vos et al. 2005; Zarate et al. 2007). Under natural conditions, plants are exposed to numerous stimuli that induce JA biosynthesis and trigger jasmonate-dependent gene expression, such as wounding, feeding damage caused by chewing insects, or exposure to MeJA emitted by neighboring plants (Reymond and Farmer 1998; Howe and Jander 2008; Rohwer and Erwin 2008). Furthermore, it is known that CMV infection can influence the interactions of several host plant species with aphids (Lowe and Strong 1961; Mauck et al. 2010). We propose that facilitation of SA biosynthesis and inhibition of JA-mediated gene expression by the $2 \mathrm{~b}$ protein may create conditions on CMV-infected plants that, in some way, will promote aphidmediated virus transmission. Thus, the $2 \mathrm{~b}$ silencing suppressor protein may be an important, albeit indirect, factor affecting transmission of CMV.

\section{MATERIALS AND METHODS}

Plant lines and virus strains.

Transgenic and nontransgenic Arabidopsis thaliana (L.) Heynh. ecotype Col-0 plants were grown on a 4:1 compost/sand mixture at $21^{\circ} \mathrm{C}$ in a custom-built growth room (Conviron, Manitoba, Canada) with a regime of $8 \mathrm{~h}$ of light and $16 \mathrm{~h}$ of darkness and light intensity of $200 \mu \mathrm{E} \mathrm{m}^{-2} \mathrm{~s}^{-1}$. Transgenic plant lines harboring the $2 b$ gene sequence from CMV strain Fny under the control of the Cauliflower mosaic virus 35S promoter have been described previously (Lewsey et al. 2007). In this work, the published $2 b$-transgenic lines $2.11 \mathrm{C}, 2.30 \mathrm{~F}, 3.7 \mathrm{H}$, and $3.13 \mathrm{~F}$ are referred to as lines $\mathrm{A}, \mathrm{B}, \mathrm{C}$, and $\mathrm{D}$, respectively.

Inoculations with TMV were conducted as described previously (Chivasa et al. 1997). Successful infection was confirmed using a double-antibody sandwich enzyme-linked immunosorbent assay kit for TMV detection (Bioreba AG, Reinach, Germany) according to manufacturer's instructions.

Virions of CMV (strain Fny) (Roossinck and Palukaitis 1990; Ryabov et al. 2001) and its 2 b gene deletion mutant, CMV $\Delta 2$ b (Ryabov et al. 2001), were propagated in tobacco and purified by the method of $\mathrm{Ng}$ and Perry (1999). CMV or CMV $\Delta 2 \mathrm{~b}$ was inoculated onto Carborundum-dusted leaves of Arabidopsis plants at the four- to six-true-leaf stage, using a cotton bud to apply a suspension of purified virions at a concentration of $100 \mu \mathrm{g} \mathrm{ml}^{-1}$ in sterile water. Mock inoculation used water only. Successful infection was confirmed using RTPCR with primers that detect and distinguish between CMV and CMV $\triangle 2$ b RNA 2 (Ziebell et al. 2007). Plants were sprayed until run-off with $1 \mathrm{mM}$ SA or $250 \mu \mathrm{M}$ MeJA (SigmaAldrich, Dorset, U.K.). SA and MeJA solutions contained $0.1 \%$ ethanol to aid dissolution of the chemicals and were amended to $\mathrm{pH} 5$ to 6.5 using $\mathrm{KOH}$. Control treatment plants were sprayed with water supplemented with $0.1 \%$ ethanol.

\section{Analyses of gene expression.}

For microarray analyses, nontransgenic Arabidopsis Col-0 plants and $2 b$-transgenic plants of line $35 S: 2 b C$ were grown under the conditions described above, then treated in parallel with SA, MeJA, and control solutions at 14.30 British summer time. Aerial tissue was harvested for RNA extraction $25 \mathrm{~h}$ afterwards. Total RNA was extracted using TRIzol reagent (Invitrogen, Carlsbad, CA, U.S.A.) according to the manufacturer's instructions. Total RNA was then cleaned using the RNeasy mini kit (Qiagen, Hilden, Germany) according to manufacturer's instructions followed by precipitation with lithium chloride (Sambrook et al. 1989). Three independent replicate experiments were conducted. Array hybridization and scanning were conducted by the Nottingham Arabidopsis Stock Centre Affymetrix Service and data deposited at NASCArrays (reference NASCARRAYS-415). Subsequently, array data were quantile normalized using the RMA method in the R BioConductor, version 1.7, packages Affy and Limma (Gentleman et al. 2004). Differential expression was determined using Limma with a corrected $P$ value $<0.05$.

Analysis of antagonism of MeJA-induced gene expression was conducted by using the normalized averaged expression values (EV) from probesets of microarray chips. EV were analyzed for the 1,268 transcripts statistically significantly differentially regulated in the comparison of nontransgenic MeJAtreated plants with nontransgenic control-treated plants. During linear regression, the EV for these transcripts in MeJA-treated nontransgenic plants were compared with the EV of the same transcripts in MeJA-treated 2b-transgenic plants using Microsoft Excel.

During analysis of expression change ratios, the EV of the same 1,268 transcripts were considered under three different treatment-plant combinations: nontransgenic MeJA-treated plants (termed "nontransgenic MeJA-treated"); $2 b$-transgenic, MeJA-treated plants (termed "2b MeJA-treated"); and nontransgenic, control-treated plants (termed "nontransgenic control"). The values for each individual transcript were used to calculate a ratio of expression change in response to MeJA between nontransgenic plants and $2 b$-transgenic plants using the following formula: Ratio of expression change $=\left(\mathrm{EV}_{2 \mathrm{~b} \text { MeJA-treated }}\right.$ $\left.\mathrm{EV}_{\text {nontransgenic control }}\right) /\left(\mathrm{EV}_{\text {nontransgenic MeJA-treated }}-\mathrm{EV}_{\text {nontransgenic control }}\right)$.

All 1,268 ratios of expression change were then ranked from lowest to highest, the rank expressed as a percentage of the total number of transcripts, then plotted as a cumulative distribution function.

Overlap between datasets of differentially regulated transcripts was assessed by comparing datasets using a custom ruby script, and the probability of overlap of observed size was calculated using the hypergeometric distribution.

RNA blotting was carried out using total RNA extracted essentially as above but omitting the use of the RNeasy mini kit. Total RNA was subjected to $1.2 \%$ agarose-formaldehyde gel electrophoresis, transferred to Hybond $\mathrm{N}+$ membrane, and UV cross-linked $(120,000 \mu \mathrm{J})$. Prehybridization was carried out for 2 to $4 \mathrm{~h}$ at $42^{\circ} \mathrm{C}$ in prehybridization solution: $0.1 \%$ sodium dodecyl sulfate (SDS) (wt/vol), $50 \%$ formamide ( $\mathrm{vol} / \mathrm{vol}), 5 \times$ standard saline citrate $(\mathrm{SSC})$ buffer $(1 \times \mathrm{SSC}$ is $0.15 \mathrm{M} \mathrm{NaCl}$ plus $0.015 \mathrm{M}$ sodium citrate), $0.1 \%$ sodium pyrophosphate (wt/vol), 5× Denhardt's solution, and sheared herring sperm DNA at $50 \mu \mathrm{g} \mathrm{ml}^{-1}$ (Sambrook et al. 1989). 32Plabeled DNA probes complementary to genes of interest were prepared by first amplifying a section of the transcript by RTPCR using transcript-specific primers. RT-PCR was conducted from total RNA of nontransgenic Arabidopsis using Bioscript and Biotaq (Bioline, London) according to the manufacturer's instructions. The products of RT-PCR were used as templates for the Prime-it II random prime labeling kit (Stratagene, Santa Clara, CA, U.S.A.). Hybridization of RNA blots was conducted overnight at $42^{\circ} \mathrm{C}$ in prehybridization solution augmented with radiolabeled probe. Blots were washed sequentially in solutions of $2 \times \mathrm{SSC}(0.1 \% \mathrm{SDS}, \mathrm{wt} / \mathrm{vol}), 0.5 \times \mathrm{SSC}$ $(0.1 \%$ SDS, wt/vol), and $0.2 \times$ SSC $(0.1 \%$ SDS, wt/vol) until background radioactivity was below $2 \mathrm{~Bq}$, then exposed to 
phosphorimaging screens and scanned using a Typhoon imaging system (GE Healthcare, Little Chalfont, Bucks, U.K.). Images were examined to confirm that saturation of the phosphorimaging screen had not occurred, then quantified using ImageQuant software (GE Healthcare). Stripping of blots was conducted by washing five times in $0.1 \times$ SSC $(0.1 \%$ SDS, $\mathrm{vol} / \mathrm{vol}$ ). Blots were finally reprobed for $18 \mathrm{~S}$ rRNA, the signals from which were quantified and used as loading controls.

RNA for Q-RT-PCR analyses was extracted as for microarray investigations. First-strand synthesis was carried out using SuperScript III (Invitrogen) reverse transcriptase, with random hexamer primers, according to the manufacturer's instructions. Q-RT-PCR was then conducted using SYBR Green JumpStart Taq ReadyMix (Sigma-Aldrich) according to the manufacturer's instructions. A stable reference gene, AT3G50590, was identified from several candidates using the methodology of Pfaffl and colleagues (2004). Primers were designed against transcripts of interest (Supplementary Table S3) and verified as producing a single, specific product by agarose gel electrophoresis and sequencing of products. Reactions were conducted in triplicate. Data were analyzed using LinRegPCR software, to give the threshold cycle number and reaction efficiency (Ramakers et al. 2003; Ruijter et al. 2009). Fold changes in transcript abundance were calculated using efficiency adjusted $\Delta \triangle \mathrm{CT}$ methodology, incorporating the reference transcript to control for loading variation (Livak and Schmittgen 2001; Yuan et al. 2008). These fold changes were expressed relative to transcript abundance in nontransgenic control-treated Arabidopsis plants.

\section{Identification of potential small RNA target sequences.}

Assessment of potential targeting of plant transcripts by small RNAs was conducted in two ways. The dataset for SAtreated nontransgenic plants versus SA-treated $2 b$-transgenic plants was analyzed by interrogating the Arabidopsis Small RNA Project database (Gustafson et al. 2005) for targeting sRNAs, due to the small size of the query dataset. The dataset for MeJA-responsive transcripts in nontransgenic plants was assessed by identifying putative targeting sRNAs in an sRNA library generated from 4-week-old nontransgenic plants (Rajagopalan et al. 2006) (GEO accession GSM118373), using the targeting rules described by Schwab and colleagues (2005).

\section{Generation of ICS1-GUS transgenic lines.}

E. coli DH5 $\alpha$ (Hanahan 1983) was used for plasmid replication; cloning was performed as previously described (Sambrook et al. 1989). Primers were designed to generate a $1.5-\mathrm{kb}$ PCR product containing the ICS1 upstream regulatory sequence with a 5' HindIII site and 3' XbaI site, shown underlined (F: 5'CGCAAGCTTGGTTTTACAACAGCAATGATGCTT-3', R: 5'-CGCTCTAGATGCAGAAATTCGTAAAGTGTTTCTT-3'), which was cloned into pGEM-T Easy (Promega Corp.) and sequenced to check for mutations. The amplicon was subcloned as a HindIII/XbaI fragment into pGreen-GUS (Hellens et al. 2000), and the resulting plasmid called pICS1p-GUS. The pICS1p-GUS plasmid was introduced into Agrobacterium tumefaciens GV3101:: pMP90::pSOUP by electroporation. Arabidopsis thaliana Col-0 was transformed using the method of floral dipping (Clough and Bent 1998) using the transformed Agrobacterium tumefaciens strain.

\section{Histochemical staining for GUS activity.}

ICS1-GUS T2 plants were germinated on agar plates supplemented with half-strength Murashige and Skoog medium and kanamycin at $50 \mu \mathrm{g} \mathrm{ml}^{-1}$ after a period of stratification at $4^{\circ} \mathrm{C}$ in the dark for 2 days. Transformants were selected after 2 weeks and transferred onto a mixture of 4:1 compost-fine vermiculite and grown under a regime of $8 \mathrm{~h}$ of light and $16 \mathrm{~h}$ of darkness (as described above) for a further 2 weeks. Rosette leaves were inoculated with Fny-CMV or TMV strain U1 or mock inoculated with water and left for 2 weeks to allow symptom development. Leaves were then removed for histochemical staining of GUS activity, as previously described (Jefferson et al. 1987), and incubated at $37^{\circ} \mathrm{C}$ overnight in the dark. The leaves were removed from the staining solution and transferred into $70 \%$ (vol/vol) ethanol to remove chlorophyll. Images were acquired using a Leica M165 FC stereomicroscope (Leica Microsystems, Wetzlar, Germany).

\section{Wounding experiments.}

To assess the transcriptional response of TPS10 to wounding, all leaves on plants that were 4 weeks old were wounded by squeezing with forceps two to three times across the midrib. All leaves were then harvested from nonwounded $(0 \mathrm{~h})$ plants and at $0.5,2$, and $4 \mathrm{~h}$ postwounding. Tissue was frozen in liquid nitrogen and RNA extracted for Q-RT-PCR, as described above. Q-RT-PCR was conducted as described above, and fold changes in TPS10 abundance calculated relative to nonwounded $(0 \mathrm{~h})$, nontransgenic leaves. Three biological replicates were analyzed.

To assess wounding-responsive JA biosynthesis, leaves of 5week-old plants were wounded by squeezing gently between forefinger and thumb, until darkening occurred. Three leaves per plant were wounded, and these leaves were then harvested 5 min postwounding. JA analysis was conducted as described below.

\section{SA and JA content determination.}

SA was extracted from leaves and analyzed by reverse-phase high-performance liquid chromatography (HPLC) and fluorescence detection as previously described (Surplus et al. 1998). Samples were the entire aboveground tissue from individual plants, replicated three times within an experiment. The experiment was repeated four times with similar results. All samples were spiked with $\left[{ }^{14} \mathrm{C}\right]-\mathrm{SA}$ (carboxyl labeled) (Sigma-Aldrich) during the first extraction stage to calculate the efficiency of recovery. JA, extracted from aerial tissues of individual plants, was analyzed by reverse-phase liquid chromatography-electrospray ionization/tandem mass spectroscopy using an Agilent 1100 HPLC coupled to an Applied Biosystems Q-TRAP 2000 (Applied Biosystems, Foster City, CA, U.S.A.) by the method of Forcat and colleagues (2008). Samples were the entire aboveground tissue from individual plants replicated five to seven times within an experiment. The experiment was repeated twice with similar results. Extracts were spiked with deuterated JA as an internal standard to calculate the efficiency of recovery. Tissue destined for SA or JA analysis was also examined by double-sandwich enzyme-linked immunosorbent assay for CMV coat protein accumulation (Bioreba AG), to confirm CMV or CMV $\Delta 2$ b systemic spread.

\section{ACKNOWLEDGMENTS}

We thank P. Palukaitis, A. Webb, J. Davies, M. Stevens, H. Ziebell, and S. Groen for valuable discussions; and the Nottingham Arabidopsis Stock Centre Affymetrix service. Research was funded by Biotechnology and Biological Research Council Grants BB/D008204/1 and BB/D014376/1, the Leverhulme Trust, and the Cambridge University Newton Trust.

\section{LITERATURE CITED}

Alamillo, J. M., Saénz, P., and García, J. A. 2006. Salicylic acid-mediated and RNA-silencing defense mechanisms cooperate in the restriction of systemic spread of plum pox virus in tobacco. Plant J. 48:217-227. 
Allen, E., Xie, Z., Gustafson, A. M., and Carrington, J. C. 2005. microRNA-directed phasing during trans-acting siRNA biogenesis in plants. Cell 121:207-221.

Baulcombe, D. 2004. RNA silencing in plants. Nature 431:356-363.

Baumberger, N., and Baulcombe, D. C. 2005. Arabidopsis ARGONAUTE1 is an RNA Slicer that selectively recruits microRNAs and short interfering RNAs. Proc. Natl. Acad. Sci. U.S.A. 102:11928-11933.

Bell, E., Creelman, R. A., and Mullet, J. E. 1995. A chloroplast lipoxygenase is required for wound-induced jasmonic acid accumulation in Arabidopsis. Proc. Natl. Acad. Sci. U.S.A. 92:8675-8679.

Brigneti, G., Voinnet, O., Li, W. X., Ji, L. H., Ding, S. W., and Baulcombe, D. C. 1998. Viral pathogenicity determinants are suppressors of transgene silencing in Nicotiana benthamiana. EMBO (Eur. Mol. Biol. Organ.) J. 17:6739-6746.

Cameron, R. K., and Zaton, K. 2004. Intercellular salicylic acid accumulation is important for age-related resistance in Arabidopsis to Pseudomonas syringae. Physiol. Mol. Plant Pathol. 65:197-209.

Canto, T., Aranda, M. A., and Fereres, A. 2009. Climate change effects on physiology and population processes of hosts and vectors that influence the spread of hemipteran-borne plant viruses. Glob. Change Biol. 15:1884-1894.

Chivasa, S., Murphy, A. M., Naylor, M., and Carr, J. P. 1997. Salicylic acid interferes with tobacco mosaic virus replication via a novel salicylhydroxamic acid-sensitive mechanism. Plant Cell 9:547-557.

Clough, S. J., and Bent, A. F. 1998. Floral dip: A simplified method forAgrobacterium-mediated transformation of Arabidopsis thaliana. Plant J. 16:735-743.

De Vos, M., Van Oosten, V. R., Van Poecke, R. M. P., Van Pelt, J. A., Pozo, M. J., Mueller, M. J., Buchala, A. J., Métraux, J.-P., Van Loon, L. C., Dicke, M., and Pieterse, C. M. J. 2005. Signal signature and transcriptome changes of Arabidopsis during pathogen and insect attack. Mol. Plant-Microbe Interact. 18:923-937.

Devoto, A., Ellis, C., Magusin, A., Chang, H.-S., Chilcott, C., Zhu, T., and Turner, J. G. 2005. Expression profiling reveals COI1 to be a key regulator of genes involved in wound- and methyl jasmonate-induced secondary metabolism, defence, and hormone interactions. Plant Mol. Biol. 58:497-513.

Diaz-Pendon, J. A., Li, F., Li, W.-X., and Ding, S.-W. 2007. Suppression of antiviral silencing by Cucumber mosaic virus $2 \mathrm{~b}$ protein in Arabidopsis is associated with drastically reduced accumulation of three classes of viral small interfering RNAs. Plant Cell 19:2053-2063.

Dong, Z., Han, M.-H., and Fedoroff, N. 2008. The RNA-binding proteins HYL1 and SE promote accurate in vitro processing of pri-miRNA by DCL1. Proc. Natl. Acad. Sci. U.S.A. 105:9970-9975.

Ellis, C., Karafyllidis, I., and Turner, J. G. 2002. Constitutive activation of jasmonate signaling in an Arabidopsis mutant correlates with enhanced resistance to Erysiphe cichoracearum, Pseudomonas syringae, and Myzus persicae. Mol. Plant-Microbe Interact. 15:1025-1030.

Endres, M. W., Gregory, B. D., Gao, Z., Foreman, A. W., Mlotshwa, S., Ge, X., Pruss, G. J., Ecker, J. R., Bowman, L. H., and Vance, V. 2010. Two plant viral suppressors of silencing require the ethylene-inducible host transcription factor RAV2 to block RNA silencing. PLoS Pathog. 6:e1000729.

Farmer, E. E., Alméras, E., and Krishnamurthy, V. 2003. Jasmonates and related oxylipins in plant responses to pathogenesis and herbivory. Curr. Opin. Plant Biol. 6:372-378.

Forcat, S., Bennett, M. H., Mansfield, J. W., and Grant, M. R. 2008. A rapid and robust method for simultaneously measuring changes in the phytohormones ABA, JA and SA in plants following biotic and abiotic stress. Plant Methods 4:16.

Gal-On, A., Kaplan, I. B., and Palukaitis, P. 1996. Characterization of cucumber mosaic virus II. Identification of movement protein sequences that influence its accumulation and systemic infection in tobacco. Virology 226:345-361.

Garcion, C., Lohmann, A., Lamodiere, E., Catinot, J., Buchala, A., Doermann, P., and Metraux, J. P. 2008. Characterization and biological function of the ISOCHORISMATE SYNTHASE2 gene of Arabidopsis. Plant Physiol. 147:1279-1287.

Gentleman, R. C., Carey, V. J., Bates, D. M., Bolstad, B., Dettling, M., Dudoit, S., Ellis, B., Gautier, L., Ge, Y., Gentry, J., Hornik, K., Hothorn, T., Huber, W., Iacus, S., Irizarry, R., Leisch, F., Li, C., Maechler, M., Rossini, A. J., Sawitzki, G., Smith, C., Smyth, G., Tierney, L., Yang, J. Y. H., and Zhang, J. 2004. Bioconductor: Open software development for computational biology and bioinformatics. Genome Biol. 5:R80.

Gilliland, A., Singh, D. P., Hayward, J. M., Moore, C. A., Murphy, A. M., York, C. J., Slator, J., and Carr, J. P. 2003. Genetic modification of alternative respiration has differential effects on antimycin A-induced versus salicylic acid-induced resistance to Tobacco mosaic virus. Plant Physiol. 132:1518-1528.

González, I., Martínez, L., Rakinita, D. V., Lewsey, M. G., Atienzo, F. A.,
Llave, C., Kalinina, N. O., Carr, J. P., Palukaitis, P., and Canto, T. 2010. Cucumber mosaic virus $2 \mathrm{~b}$ protein subcellular targets and interactions: Their significance to RNA silencing suppressor activity. Mol. PlantMicrobe Interact. 23:294-303.

Goto, K., Kobori, T., Kosaka, Y., Natsuaki, T., and Masuta, C. 2007. Characterization of silencing suppressor $2 \mathrm{~b}$ of Cucumber mosaic virus based on examination of its small RNA-binding abilities. Plant Cell Physiol. 48:1050-1060.

Gustafson, A. M., Allen, E., Givan, S., Smith, D., Carrington, J. C., and Kasschau, K. D. 2005. ASRP: The Arabidopsis small RNA project database. Nucleic Acids Res. 33:D637-640.

Han, M.-H., Goud, S., Song, L., and Fedoroff, N. 2004. The Arabidopsis double-stranded RNA-binding protein HYL1 plays a role in microRNA-mediated gene regulation. Proc. Natl. Acad. Sci. U.S.A. 101:1093-1098.

Hanahan, D. 1983. Studies on transformation of Escherichia coli with plasmids. J. Mol. Biol. 166:557-580.

Hellens, R. P., Edwards, E. A., Leyland, N. R., Bean, S., and Mullineaux, P. M. 2000. pGreen: A versatile and flexible binary Ti vector for Agrobacterium-mediated plant transformation. Plant Mol. Biol. 42:819832.

Howe, G. A., and Jander, G. 2008. Plant immunity to insect herbivores. Annu. Rev. Plant Biol. 59:41-66.

Jefferson, R. A., Kavanagh, T. A., and Bevan, M. W. 1987. GUS fusions: $\beta$-glucuronidase as a sensitive and versatile gene fusion marker in higher plants. EMBO (Eur. Mol. Biol. Organ.) J. 6:3901-3907.

Ji, L. H., and Ding, S. W. 2001. The suppressor of transgene RNA silencing encoded by Cucumber mosaic virus interferes with salicylic acidmediated virus resistance. Mol. Plant-Microbe Interact. 14:715-724.

Kasschau, K. D., Xie, Z., Allen, E., Llave, C., Chapman, E. J., Krizan, K. A., and Carrington, J. C. 2003. P1/HC-Pro, a viral suppressor of RNA silencing, interferes with Arabidopsis development and miRNA unction. Dev. Cell 4:205-217.

Koornneef, A., and Pieterse, C. M. J. 2008. Cross talk in defense signaling. Plant Physiol. 146:839-844.

Lewsey, M., Robertson, F. C., Canto, T., Palukaitis, P., and Carr, J. P. 2007. Selective targeting of miRNA-regulated plant development by a viral counter-silencing protein. Plant J. 50:240-252.

Lewsey, M., Palukaitis, P., and Carr, J. P. 2009a. Plant-virus interactions: Defence and counter-defence. Pages 134-176 in: Molecular Aspects of Plant Disease Resistance. Wiley-Blackwell, Oxford.

Lewsey, M., Surette, M., Robertson, F. C., Ziebell, H., Choi, S. H., Ryu, K H., Canto, T., Palukaitis, P., Payne, T., Walsh, J. A., and Carr, J. P. $2009 \mathrm{~b}$. The role of the Cucumber mosaic virus $2 \mathrm{~b}$ protein in viral movement and symptom induction. Mol. Plant-Microbe Interact. 22:642-654.

Livak, K. J., and Schmittgen, T. D. 2001. Analysis of relative gene expression data using real-time quantitative PCR and the 2(-delta delta C(T)) method. Methods 25:402-408.

Llave, C., Xie, Z., Kasschau, K. D., and Carrington, J. C. 2002. Cleavage of Scarecrow-like mRNA targets directed by a class of Arabidopsis miRNA. Science 297:2053-2056

Lowe, S., and Strong, F. E. 1961. The unsuitability of some viruliferous hosts as hosts for the green peach aphid Myzus persicae. J. Econ. Entomol. 56:307-309.

Malamy, J., Carr, J. P., Klessig, D. F., and Raskin, I. 1990. Salicylic acid: A likely endogenous signal in the resistance response of tobacco to viral infection. Science 250:1002-1004.

Maleck, K., Levine, A., Eulgem, T., Morgan, A., Schmid, J., Lawton, K. A., Dangl, J. L., and Dietrich, R. A. 2000. The transcriptome of Arabidopsis thaliana during systemic acquired resistance. Nat. Genet. 26:403-410.

Mauck, K. E., De Moraes, C. M., and Mescher, M. C. 2010. Deceptive chemical signals induced by a plant virus attract insect vectors to inferior hosts. Proc. Natl. Acad. Sci. U.S.A. 107:3600-3605.

Mayers, C. N., Lee, K.-C., Moore, C. A., Wong, S.-M., and Carr, J. P. 2005. Salicylic acid-induced resistance to Cucumber mosaic virus in squash and Arabidopsis thaliana: Contrasting mechanisms of induction and antiviral action. Mol. Plant-Microbe Interact. 18:428-434.

Morris, K., A.-H. Mackerness, S., Page, T., John, C. F., Murphy, A. M., Carr, J. P., and Buchanan-Wollaston, V. 2000. Salicylic acid has a role in regulating gene expression during leaf senescence. Plant J. 23:677686.

Murphy, A. M., and Carr, J. P. 2002. Salicylic acid has cell-specific effects on Tobacco mosaic virus replication and cell-to-cell movement. Plant Physiol. 128:552-563.

Naylor, M., Murphy, A. M., Berry, J. O., and Carr, J. P. 1998. Salicylic acid can induce resistance to plant virus movement. Mol. Plant-Microbe Interact. 11:860-868.

$\mathrm{Ng}$, B., and Perry, K. 1999. Stability of the aphid transmission phenotype in cucumber mosaic virus. Plant Pathol. 48:388-394. 
Palukaitis, P., and Garcia-Arenal, F. 2003. Cucumoviruses. Adv. Virus Res. 62:241-323

Pandey, S. P., Shahi, P., Gase, K., and Baldwin, I. T. 2008. Herbivoryinduced changes in the small-RNA transcriptome and phytohormone signaling in Nicotiana attenuata. Proc. Natl. Acad. Sci. U.S.A. 105:4559-4564.

Pfaffl, M. W., Tichopad, A., Prgomet, C., and Neuvians, T. P. 2004. Determination of stable housekeeping genes, differentially regulated target genes and sample integrity: BestKeeper-Excel-based tool using pair-wise correlations. Biotechnol. Lett. 26:509-515.

Pruss, G. J., Lawrence, C. B., Bass, T., Li, Q. Q., Bowman, L. H., and Vance, V. 2004. The potyviral suppressor of RNA silencing confers enhanced resistance to multiple pathogens. Virology 320:107-120.

Rajagopalan, R., Vaucheret, H., Trejo, J., and Bartel, D. P. 2006. A diverse and evolutionarily fluid set of microRNAs in Arabidopsis thaliana. Genes Dev. 20:3407-3425.

Ramakers, C., Ruijter, J. M., Deprez, R. H. L., and Moorman, A. F. M. 2003. Assumption-free analysis of quantitative real-time polymerase chain reaction (PCR) data. Neurosci. Lett. 339:62-66.

Raupach, G. S., Liu, L., Murphy, J. F., Tuzun, S., and Kloepper, J. W. 1996. Induced systemic resistance in cucumber and tomato against cucumber mosaic cucumovirus using plant growth-promoting rhizobacteria (PGPR). Plant Dis. 80:891-894.

Reymond, P., and Farmer, E. E. 1998. Jasmonate and salicylate as global signals for defense gene expression. Curr. Opin. Plant Biol. 1:404-411.

Rohwer, C. L., and Erwin, J. E. 2008. Horticultural applications of jasmonates: A review. J. Hortic. Sci. Biotechnol. 83:283-304.

Roossinck, M. J., and Palukaitis, P. 1990. Rapid induction and severity of symptoms in zucchini squash (Cucurbita pepo) map to RNA 1 of cucumber mosaic virus. Mol. Plant-Microbe Interact. 3:188-192.

Ruijter, J. M., Ramakers, C., Hoogaars, W. M. H., Karlen, Y., Bakker, O., van den Hoff, M. J. B., and Moorman, A. F. M. 2009. Amplification efficiency: Linking baseline and bias in the analysis of quantitative PCR data. Nucleic Acids Res. 37:e45.

Ryabov, E. V., Fraser, G., Mayo, M. A., Barker, H., and Taliansky, M 2001. Umbravirus gene expression helps Potato leafroll virus to invade mesophyll tissues and to be transmitted mechanically between plants. Virology 286:363-372.

Sambrook, J., Fritsch, E. F., and Maniatis, T. 1989. Molecular Cloning: A Laboratory Manual. Cold Spring Harbor Laboratory Press, Cold Spring Harbor, NY, U.S.A.

Schenk, P. M., Kazan, K., Wilson, I., Anderson, J. P., Richmond, T., Somerville, S. C., and Manners, J. M. 2000. Coordinated plant defense responses in Arabidopsis revealed by microarray analysis. Proc. Natl. Acad. Sci. U.S.A. 97:11655-11660.

Schwab, R., Palatnik, J. F., Riester, M., Schommer, C., Schmid, M., and Weigel, D. 2005. Specific effects of microRNAs on the plant transcriptome. Dev. Cell 8:517-527.

Sels, J., Mathys, J., De Coninck, B. M. A., Cammue, B. P. A., and De Bolle, M. F. C. 2008. Plant pathogenesis-related (PR) proteins: A focus on PR peptides. Plant Physiol. Biochem. 46:941-950.

Singh, D. P., Moore, C. A., Gilliland, A., and Carr, J. P. 2004. Activation of multiple antiviral defence mechanisms by salicylic acid. Mol. Plant Pathol. 5:57-63.

Soards, A. J., Murphy, A. M., Palukaitis, P., and Carr, J. P. 2002. Virulence and differential local and systemic spread of Cucumber mosaic virus in tobacco are affected by the CMV $2 \mathrm{~b}$ protein. Mol. Plant-Microbe Interact. 15:647-653.

Spoel, S. H., Koornneef, A., Claessens, S. M. C., Korzelius, J. P., Van Pelt, J. A., Mueller, M. J., Buchala, A. J., Métraux, J.-P., Brown, R., Kazan, K., Van Loon, L. C., Dong, X., and Pieterse, C. M. J. 2003. NPR1 modulates cross-talk between salicylate- and jasmonate-dependent defense pathways through a novel function in the cytosol. Plant Cell 15:760-770.
Surplus, S. L., Jordan, B. R., Murphy, A. M., Carr, J. P., Thomas, B., and Mackerness, A.-H. S. 1998. Ultraviolet-B-induced responses in Arabidopsis thaliana: Role of salicylic acid and reactive oxygen species in the regulation of transcripts encoding photosynthetic and acidic pathogenesis-related proteins. Plant Cell Environ. 21:685-694.

Ton, J., van Pelt, J. A., van Loon, L. C., and Pierterse, C. M. J. 2002. Differential effectiveness of salicylate-dependent and jasmonate/ethylene-dependent induced resistance in Arabidopsis. Mol. Plant-Microbe Interact. 15:27-34

van Wees, S. C., de Swart, E. A., van Pelt, J. A., van Loon, L. C., and Pieterse, C. M. 2000. Enhancement of induced disease resistance by simultaneous activation of salicylate- and jasmonate-dependent defense pathways in Arabidopsis thaliana. Proc. Natl. Acad. Sci. U.S.A. 97:8711-8716.

Vaucheret, H. 2008. Plant ARGONAUTES. Trends Plant Sci. 13:350-358.

Whitham, S. A., Quan, S., Chang, H.-S., Cooper, B., Estes, B., Zhu, T., Wang, X., and Hou, Y.-M. 2003. Diverse RNA viruses elicit the expression of common sets of genes in susceptible Arabidopsis thaliana plants. Plant J. 33:271-283.

Wildermuth, M. C., Dewdney, J., Wu, G., and Ausubel, F. M. 2001 Isochorismate synthase is required to synthesize salicylic acid for plant defence. Nature 414:562-565.

Wong, C. E., Carson, R. A. J., and Carr, J. P. 2002. Chemically induced virus resistance in Arabidopsis thaliana is independent of pathogenesisrelated protein expression and the NPR1 gene. Mol. Plant-Microbe Interact. 15:75-81.

Xie, Z., Fan, B., Chen, C., and Chen, Z. 2001. An important role of an inducible RNA-dependent RNA polymerase in plant antiviral defense. Proc. Natl. Acad. Sci. U.S.A. 98:6516-6521.

Yang, J.-Y., Iwasaki, M., Machida, C., Machida, Y., Zhou, X., and Chua, N.-H. 2008. betaC1, the pathogenicity factor of TYLCCNV, interacts with AS1 to alter leaf development and suppress selective jasmonic acid responses. Genes Dev. 22:2564-2577.

Yang, S.-J. J., Carter, S. A., Cole, A. B., Cheng, N.-H. H., and Nelson, R. S. 2004. A natural variant of a host RNA-dependent RNA polymerase is associated with increased susceptibility to viruses by Nicotiana benthamiana. Proc. Natl. Acad. Sci. U.S.A. 101:6297-6302.

Yu, D., Fan, B., MacFarlane, S. A., and Chen, Z. 2003. Analysis of the involvement of an inducible Arabidopsis RNA-dependent RNA polymerase in antiviral defense. Mol. Plant-Microbe Interact. 16:206-216.

Yuan, J. S., Wang, D., and Stewart, C. N. 2008. Statistical methods for efficiency adjusted real-time PCR quantification. Biotechnol. J. 3:112123.

Zarate, S. I., Kempema, L. A., and Walling, L. L. 2007. Silverleaf whitefly induces salicylic acid defenses and suppresses effectual jasmonic acid defenses. Plant Physiol. 143:866-875.

Zehnder, G., Yao, C., Murphy, J., Sikora, E., and Kloepper, J. 2000. Induction of resistance in tomato against cucumber mosaic cucumovirus by plant growth-promoting rhizobacteria. Biocontrol 45:127-137.

Zhang, X., Yuan, Y.-R., Pei, Y., Lin, S.-S., Tuschl, T., Patel, D. J., and Chua, N.-H. 2006. Cucumber mosaic virus-encoded 2b suppressor inhibits Arabidopsis Argonaute1 cleavage activity to counter plant defense. Genes Dev. 20:3255-3268.

Ziebell, H., Payne, T., Berry, J. O., Walsh, J. A., and Carr, J. P. 2007. A Cucumber mosaic virus mutant lacking the $2 \mathrm{~b}$ counter-defence protein gene provides protection against wild-type strains. J Gen. Virol. $88: 2862-2871$

\section{AUTHOR-RECOMMENDED INTERNET RESOURCES}

NASC's International Affymetrix service: affymetrix.arabidopsis.info Arabidopsis small RNA project: asrp.cgrb.oregonstate.edu 